\title{
MASS THERAPEUTIC EDUCATION FOR MONITORING SUICIDAL BEHAVIOR IN COMMUNITY
}

\author{
Fadhillah Salman Sofyan ${ }^{1}$ \\ Correspondence: sofyansalman@ub.ac.id \\ ${ }^{1}$ Medical Faculty Brawijaya University Indonesia
}

\begin{abstract}
Background: Suicide is a worrying problem in Indonesia because of increase in case reported. There has been an increase in suicide rates both globally and in Indonesia. The negative stigma, lack of education, and lack of understanding of the role of the community make it difficult to reduce the number of suicides. This study aims to discuss mass therapeutic education for monitoring suicidal behavior in community. Method: Researchers used 15 journals and literature that discuss the impact and vulnerability of distance learning on students' mental health conditions.

Conclusion: The role of society in reducing the suicide rate is very much needed. The community can help make early detection of suicide. Society can help prevent suicidal ideas from arising in those around them. The public can provide information to the authorities and give advice for suicide perpetrators to visit a health center. The role of the community can be integrated in a structured and neat system that can make suicide prevention efforts become optimal.
\end{abstract}

Keywords: Suicidal, community, therapeutic education, mental health.

\section{Article History:}

Received: January 16, 2021

Accepted: February 5, 2021

Published: March 31, 2021
Cite this as: Sofyan, F.S. Mass therapeutic education for monitoring suicidal behavior in community. Journal of Psychiatry Psychology and Behavioral Research; 2021.1:16-19.

\section{INTRODUCTION}

Suicide is a form of escape from the real world, or running from a situation that cannot be tolerated, or is a form of regression to want to return to a state of pleasure, comfort, and peace. The rise of suicide events with a high suicide rate is an interesting phenomenon. The phenomenon of suicide in Indonesia is a crucial and worrying problem. Indonesia as a country that adheres to a culture of collectivity cannot be avoided from the relatively high number of the phenomenon of suicide. Suicide perpetrators create the easiest way to leave the problem behind by taking their own life. As if they have no hope of life or the desire to continue the struggle for life. It is still considered by some people that suicide can be a shortcut for alternative solutions to solve the problems at hand. ${ }^{1}$

Suicide is a global problem. According to WHO, in 2015 more than 800,000 people each year die from suicide. In the United States, teenage suicide was the second leading cause of death in 2013. The average number of Indonesians who die as a result of suicide is 24 per 100,000 population in other words as many as 50,000 people in one year. This prevalence tends to increase every year. This condition is almost close to the suicide rate that occurred in China, which amounted to 250,000 and in India 100,000 people within one year. ${ }^{15}$

Suicide is one of the mental health issues that is still taboo to discuss and invites negative perceptions. The reluctance to talk about suicide in the public domain is mainly due to the stigma of suicide that is still strong in society. The stigma of suicide itself is erroneous view, a sense of fear or anger that it provoked, or even discrimination in the form of avoidance, humiliation, or even violence in people who have attempted suicide. The stigma associated with suicide and discrimination does not only occur to people who commit suicide but also to those closest to them who are affected after a death due to suicide. In other words, the stigma against suicide does not only stop at those who try or die from suicide but also those who are left behind because of suicide. ${ }^{2}$

Law Number 18 of 2014 concerning Mental Health in article 1 paragraph 4 states that mental health efforts are any activity to realize the optimal degree of mental health for each individual, family and community with promotive, preventive, curative and rehabilitative approaches that are held in a comprehensive, integrated and sustainable manner by the Government, Local Government, and / or the community. According to the mandate of the law, the management of psychological 
problems is not only the task of the government, but also the role of the community in it. ${ }^{16}$

Knowing the high rate of suicide and there is a tendency to increase every year. Meanwhile, talking about the issue of suicide is still taboo in the public domain because of the negative stigma that is still attached to society. The negative stigma causes suicide offenders, attempted suicide perpetrators, to the people closest to the suicide perpetrators to be treated inappropriately. Referring to Law Number 18 of 2014 where a community's role is needed in the management of psychological problems, it is necessary to have public knowledge about behaviors that can lead to suicide and what things can be done by the community to prevent suicide.

\section{METHOD}

Researchers used 15 journals and literature that discuss mass therapeutic education for monitoring suicidal behavior in community.

\section{DISCUSSION}

Causes of Suicide. Psychiatric disorders can be a risk factor for suicide, for example is depression, bipolar disorder, anxiety disorders, schizophrenia and other psychoses , alcohol or other substance abuse, and personality disorders. Other risk factors that can lead to suicidal behavior include stressful events, child-parent relationship problems, parental divorce , family history, chronic disease history, heredity factors, and past suicide attempts . Despair and poor problem-solving abilities are also associated with suicidal behavior. ${ }^{19,13}$

Depression is a major factor in the causes of suicide. According to Tentama et al., There are several factors that trigger depression in survivors of suicide attempts in Gunungkidul, that is helplessness and deep sadness due to losing their job, husband, and child at almost the same time. The existence of trauma after losing a limb that had to be amputated, a past history of frequent bullying since childhood and rejection from the community. ${ }^{15}$

Asih and Hiryanto stated, based on personality psychology, the strongest reasons for the perpetrators of suicide, that is not being able to face pressure, suffering from mental illnesses such as depression as much as $46 \%$ and $24 \%$ due to prolonged chronic pain. Depression because of self-pressure due to problems in the family, economy, breakups that result in feelings of hopelessness can be causes of suicide. In line with research conducted by Tapung et al. regarding the Youth Community in Manggarai, there are several factors that can cause a person to commit suicide. Suicide is caused by the failure of a person to manage problems in his life such as social, economic, cultural, health, or fatalistic matters such as breakups and body shaming. The use of social media can also be a trigger suicide because of the access to the criminal contents, war, murder, and suicide, and even social media can be the place of bullying. In addition, the reduction of norms and social control from family, society, religion, and the state has also triggered suicide. ${ }^{1,10}$

The data obtained by Mallo and Ronda from 86 adolescent respondents aged $15-17$ years showed that 16 people or $18.6 \%$ had a tendency to commit suicide attempts, 35 people or $40.7 \%$ had the potential to attempt suicide, and the rest never have suicidal thoughts or do things that are risky. The reasons that have been investigated, why adolescents aged 15-17 years old in Makassar have the intention to commit suicide are as follows. First, there is a trend in the environment that encourages someone to have a tendency to commit suicide. Second, adolescents with depression, wrong self-concept, and the family relationship is not harmonious, such as divorce or a parent who is too much push their children. Their wrong selfconcept makes them feel unwanted, unworthy and that no one loves them. This wrong self-concept is also influenced by their same-aged friends. Adolescents try to be what their friends want so that they can be accepted and recognized by their friend groups. Discussion about self-concept is linear with Ratih and Tobing's research on 5 perpetrators of suicide attempts in Bali. This research shows that young adult male suicide perpetrators in Bali do not fully have a positive selfconcept, but tend to show negative self-concept characteristics in their self. Young adult male suicide perpetrators who were respondents to this study tended to have negative selfevaluations, lack of self-respect, and have low self-esteem. ${ }^{5,12}$ A meta-analysis study conducted by Valentina and Helmi showed that powerlessness was a predictor of suicidal behavior. This study has also looked at the relationship between powerlessness and suicidal behavior with a variety of clinical and non-clinical subjects, involving samples from studies in Western and Eastern countries. Powerlessness is a hope, and the terminology of powerlessness often implies negative feelings and negative outcomes. Powerlessness will increase during times of emotional stress and lessen as the stress decreases. Powerlessness can also be defined as a belief that the future is scary and the problems faced by them have no way out. ${ }^{17}$ literature review with a sample of people with LGBT shows a strong correlation with the incidence of suicide and self-harm. Of the 26 studies that have been conducted to find a correlation between the incidence of suicide and selfharm with LGBT, 18 studies or $69.2 \%$ show the emergence of suicidal ideation and desire in this population. Meanwhile, 8 studies show that completed suicide is common in this population. $^{6}$

How to Prevent and Respond to Suicide? Providing counseling is a preventive effort, especially regarding mental health, aims to prevent mental problems, prevent the emergence and/or recurrence of mental disorders, reduce risk factors due to mental disorders in the community in general or individually, and prevent the impact of psychosocial problems carried out in the family environment, institutions, and society. Education is promotive measures that can reduce negative stigmatization towards suicide and raise awareness about role of the community. ${ }^{16,2}$ One of solution to reducing suicide is to use psychosocial mentoring therapy or family-based mentoring therapy. So in addition to providing health education, in doing assistance to survivors of suicide. Assistance activities are carried out to convince victims to be aware of their existence and meaning in life, to know their roles and functions in the social environment, and to realize their own potentials to be developed. ${ }^{15}$

Social attention or support becomes important especially when someone is experiencing adversity or problems. Individuals will tend to be stronger when someone accompanies them or to listen to their complaints. This is different from individuals who are alone in dealing with problems due to burdens, pain and even anger, because they felt as if they are alone so that giving up on life may come to mind. Building a close relationship with the victim, being attentive, listening, appreciating his feelings and understanding his emotions are 
ways that can prevent suicide. This is because these actions can provide social support to the victim. Social support tends to be of particular relevance to suicide prevention. ${ }^{15,8}$

The need to involve religious leaders is something that can be implemented in preventing suicidal behavior. This can encourage individuals to get closer to God and increase their worship routine. Based on the Systematic Review conducted by Litaqia and Permana, religious support can prevent individuals from have suicidal ideation and increase their life expectancy. Religious support can be provided based on individuals who tend to think that a problem that comes to them is a sign that they feel abandoned by God, feel punished, feel that other people do not respect their religious beliefs, often they also relate a problem to a magical event that has something to do with demons, and unable to find meaning in life. $^{4}$

The formation of a rapid reaction team can help with suicides. Quick response comes from information from the surrounding community. Some testimonies from people who failed to commit suicide because there were whispers, hallucinations about committing suicide. People who hear complaints from someone who gets a whisper need a quick response, so that they can be handled seriously and as early as possible. The suicide prevention team in carrying out the task was divided into three working groups whose task was to map someone who was indicated as a suicide perpetrator. In addition, the addition of health facilities at the puskesmas is needed to accommodate critical conditions as a provision of services for the community. ${ }^{1}$ The use of information technology can be used to detect suicidal ideas. The use of algorithms for emerging phrases then processed by a system called the Convolutional Neural Network (CNN) and Long Short-Term Memory (LSTM), as well as a combination of the two (LSTMCNN) . Research conducted by Tadesse et.al., shows that the use of computer algorithms is effective in detecting suicidal ideas on the social media Reddit. This system still needs improvement by adding data about phrases that lead to suicidal ideas and improving the possibility of bias in translating phrases that appear on the internet. ${ }^{14}$

\section{CONCLUSION}

The emergence of suicidal ideas can be triggered by many factors. We cannot know the thoughts of a person. However, we can slow down or prevent suicidal ideas from arising. Steps that can be taken are to identify health conditions, behaviors, and other social factors that can be risk factors for suicide. Within the scope of society, it is necessary to make promotional and preventive efforts. The community needs to get education, the community can also provide assistance to survivors of suicide, provide social support to individuals who are experiencing problems, involving religious leaders can also be done to prevent the emergence of suicidal ideas. To deal with emergency conditions, a rapid reaction team can be formed to thwart suicide attempts. In the scope of technology, a computer program can be developed that can detect suicidal ideas written on social media. The integration of mental health management can be in the form of DSSJ, where to achieve its success requires the role of the community from various fields, driven by the puskesmas and village health cadres.
Community Based Program. According to Ono et.al. conducting experimental research in urban and rural areas of Japan, community-based multimodal interventions can be applied in all regions. However, it is more effective in rural areas than in urban areas because the decrease in the number of suicide attempts has been more drastic in rural areas. In this study, the number of suicide attempts in the intervention population was lower than in the control population. However, this applies to attempted suicide, there is a change that is not drastic to the case completed suicide (Ono et.al., 2013).

Desa Siaga Sehat Jiwa (DSSJ) is an implementation of basic mental health services with the concept of a community mental health nurse approach . DSSJ is formed so that the community is more responsive to the early signs of mental disorders and understands what to do. Families often choose to surrender people with mental disorders entirely to mental hospitals and rely more on drugs than to improve the psychological environment condition to support the healing of people with mental disorders. The DSSJ program helps reduce the stigma regarding mental disorders that arise in society. The community is more accepting of the existence of people with mental disorders than before the formation of the DSSJ. Evaluation conducted by Wasniyati et al. The implementation of DSSJ at Puskesmas Galur II, Kulonprogo, Yogyakarta shows that the program can run consistently and continuously when students of educational institutions carry out community practices at the puskesmas. There are several obstacles in implementing the program, including human resources, communication, funding, territoriality, and policies. According to Kurniawan et al., The role of the DSSJ health cadres is very crucial in realizing DSSJ. The cadres sincere intention and sense of responsibility are the keys to the cadres persistence in carrying out their duties to help patients and families, so that DSSJ can be realized in the working area of the Bantur District Health Center, Malang. Apart from health cadres, training needs to be carried out for people who have the potential to have a lot of interaction with the community. This training can increase the detection of behaviors that lead to suicide. Training can be conducted for village officials, security guards, religious leaders, and another member of community. ${ }^{11,18,3,7}$

\section{REFERENCES}

1. Asih, K. Y., \& Hiryanto, H. (2020). Rekonstruksi Sosial Budaya Fenomena Bunuh Diri Masyarakat Gunungkidul. Diklus: Jurnal Pendidikan Luar Sekolah, 4(1), 21-31.

2. Febriawan, I. M. (2020). Pelatihan Rise and Shine sebagai metode psikoedukasi: Bisakah menurunkan stigma bunuh diri?. Jurnal Psikologi Sosial, 18(3), 277-291.

3. Kurniawan, D., Winarni, I., \& Fevriasanty, F. I. (2017). STUDI FENOMENOLOGI: PENGALAMAN KADER DESA SIAGA SEHAT JIWA (DSSJ) DI WILAYAH KERJA PUSKESMAS KECAMATAN BANTUR MALANG. Jurnal Keperawatan Florence, 2(1).

4. Litaqia, W., \& Permana, I. (2019). Peran Spiritualitas dalam Mempengaruhi Resiko Perilaku Bunuh Diri: A Literature Review. Jurnal Keperawatan Respati Yogyakarta, 6(2), 615-624. 
5. Mallo, H., \& Ronda, D. (2010). Analisis Faktor Penyebab Utama Kecenderungan Bunuh Diri di Kalangan Remaja yang Berusia 15-17 Tahun di Makassar. Jurnal Jaffray, 8(1), 35-43.

6. Marshall, E., Claes, L., Bouman, W. P., Witcomb, G. L., \& Arcelus, J. (2016). Non-suicidal self-injury and suicidality in trans people: a systematic review of the literature. International review of psychiatry, 28(1), 58-69.

7. Menon, V., Subramanian, K., Selvakumar, N., \& Kattimani, S. (2018). Suicide prevention strategies: An overview of current evidence and best practice elements. International Journal of Advanced Medical and Health Research, 5(2), 43.

8. Nugrawati, N., \& Akhir, M. (2016). Gantung Diri sebagai Penyimpangan Sosial Terhadap Norma Agama. Jurnal Equilibrium Pendidikan Sosiologi, 9(1), 11-19.

9. Ono, Y., Sakai, A., Otsuka, K., Uda, H., Oyama, H., Ishizuka, N., ... \& Yonemoto, N. (2013). Effectiveness of a multimodal community intervention program to prevent suicide and suicide attempts: a quasi-experimental study. PLoS One, 8(10), e74902.

10. Payong, M. R., Tapung, M. M., \& Regus, M. (2020). MEMBANGUN KESADARAN KRITIS ORANG MUDA MANGGARAI DALAM MENANGGAPI FENOMENA BUNUH DIRI DENGAN PENDEKATAN CATEGORICAL GROUP GUIDANCE. Randang Tana-Jurnal Pengabdian Masyarakat, 3(3), 107-119.

11. Putri, A. S., Martiningtyas, M. A., Sagala, A. E. B., Erawan, G. N., Yana, I. P. A., Matulu, S., ... \& Yolanda, Y. T. (2013). Era Baru Kesehatan Mental Indonesia: sebuah Kisah dari Desa Siaga Sehat Jiwa (DSSJ). Jurnal Psikologi, 40(2), 169-180.

12. Ratih, A. S. W. K., \& Tobing, D. H. (2016). Konsep Diri Pada Pelaku Percobaan Bunuh Diri Pria Usia dewasa Muda di Bali. Jurnal Psikologi Udayana, 5670.

13. Schwartz-Lifshitz, M., Zalsman, G., Giner, L., \& Oquendo, M. A. (2012). Can we really prevent suicide?. Current psychiatry reports, 14(6), 624-633.

14. Tadesse, M. M., Lin, H., Xu, B., \& Yang, L. (2020). Detection of suicide ideation in social media forums using deep learning. Algorithms, 13(1), 7.

15. Tentama, F., Mulasari, S. A., Sukesi, T. W., \& Sulistyawati, S. (2019). Penyuluhan dan Pendampingan pada Korban Selamat Percoban Bunuh Diri di Gunung Kidul. International Journal of Community Service Learning, 3(1), 27-32.

16. Undang Undang No 18 Tahun 2014 Tentang Kesehatan Jiwa

17. Valentina, T. D., \& Helmi, A. F. (2016). Ketidakberdayaan dan perilaku bunuh diri: Metaanalisis. Buletin Psikologi, 24(2), 123-135.

18. Wasniyati, A., Hasthayoga LB, B., \& Siwi Padmawati, R. (2014). Evaluasi Program Desa Siaga Sehat Jiwa (DSSJ) di Wilayah Puskesmas Galur II Kabupaten Kulon Progo Yogyakarta.

19. Zulaikha, A., \& Febriyana, N. (2018). Bunuh Diri pada Anak dan Remaja. Jurnal Psikiatri Surabaya, 7(2), 11-21. 